\title{
Introduction to special issue on the ecology of clonal plants
}

\author{
Katherine L. Gross • Tomáš Herben • \\ Jitka Klimešová (D)
}

Received: 26 October 2017 / Revised: 00 Month 0000 / Accepted: 13 November 2017 / Published online: 8 December 2017

(C) Institute of Botany, Academy of Sciences of the Czech Republic 2017

\section{Introduction}

Clonality is one of the defining features of the whole plant kingdom. It underlies a number of functions that plant species have, from reproduction and competition to disturbance responses. Although clonality is present in the majority of plant species in Central Europe (53\%), the importance of clonality in affecting colonization, persistence, abundance or interactions with other species has not been a focus of plant functional ecology. The international conference on clonality that began almost 30 years ago with a small meeting in the Netherlands has since provided an important platform for exchange of ideas and research among ecologists

K. L. Gross

W.K. Kellogg Biological Station, Michigan State University, Hickory Corners, MI, USA

K. L. Gross

Department of Plant Biology, Michigan State University, East Lansing, MI, USA

\section{K. L. Gross}

Ecology, Evolution and Behavioral Biology program, Michigan

State University, East Lansing, MI, USA

T. Herben

Department of Botany, Charles University, Prague,

Czech Republic

J. Klimešová $(\square)$

Department of Functional Ecology, Institute of Botany CAS,

Třeboň, Czech Republic

e-mail: jitka.klimesova@ibot.cas.cz interested in clonality in plants. The most recent conference, CLONE 2015, held in Třeboň, Czech Republic provided the motivation for this special issue.

Research on the biology of clonal plants has progressed substantially since the first conference, both by articulating well established topics and by adding new ones. Still, a number of topics relevant to understanding the wide-spread occurrence of clonality in plants have received little attention. In the collection of papers included in this special issue on the ecology of clonal plants, we have included several papers that explore new ideas that, we hope, will inspire further research into the role of clonality in plant ecological strategies.

\section{Clonality at the level of individuals and populations}

Most of the papers in this special issue focus on understanding clonality at the level of individual plants. They contribute to the further understanding of the core process that makes clonal plants successful in heterogeneous environments, specifically the importance of resource sharing via connections between ramets. Included here are papers describing the role of clonal integration in plant performance under different conditions (Portela and Roiloa 2017; Wan et al. 2017; Wang et al. 2017), benefits of ramet connections in response to nutrient availability (Duchoslavová and Weiser 2017), with a welcome addition of one of the few studies on nutrient sharing in a clonal tree (Bretfeld et al. 2017). Also in this issue are three studies done at the population 
level, which has been rarely explored in studies on clonal plants. Two examine the demography of clonal species (Martínková and Klimešová 2017; Scherrer et al. 2017), and the third evaluates the coverage of European clonal plants in the first comprehensive database of matrix population models and the quality of data therein (COMPADRE; Janovský et al. 2017). We expect that the findings in these papers will stimulate further discussions about a methodology for studying demography in clonal species that is both feasible (e.g. defining the 'individual') and captures key demographic features that are unique to clonal species (e.g. the capacity to increase population size through clonal 'reproduction').

\section{Clonality at the community level}

This issue also includes several papers that focus on the role of clonality at the community level. The paper by Vojtkó et al. (2017) provides one of the first in-depth analyses of within- and between-community patterns of clonal traits; Gross and Mittelbach (2017) and Lopp and Sammul (2017) report on the differential effects of nutrient addition on clonal species and the impacts this has for understanding diversity patterns in communities. The paper by Brooker (2017) focuses on the link between facilitation and plant clonality, and we hope that it will spark further research into interspecific relationships with clonal plants. The contributions by Bartušková et al. (2017) and Filartiga et al. (2017) provide datasets on clonal traits, a resource that is indispensable both for trait-based analyses of community assembly and for a better understanding of the evolution of clonality.

\section{Clonality in microevolution}

In contrast to previous special issues from the clonal conference, we included only a few papers on evolutionary patterns of clonality. This was intentional, as there is a forthcoming special issue of Evolutionary Ecology that includes several papers presented at the CLONE 2015 conference. Here we present two papers with evolutionary focus: James et al. (2017) evaluate the genetic diversity of exclusively clonal species for needs of species conservation; Ahn et al. (2017) present the epigenetic diversity of Aspen stands, which can be important for their performance as well as for the evolution of species with low genetic variation.

\section{Concluding remarks}

The presentations and discussions at CLONE 2015, as well as the papers included in this special issue, make it clear that a number of topics have been neglected that are important for understanding the biology of clonal plants and the world-wide occurrence of this mode of growth. A major challenge of clonal plant biology for the future is to bring attention to these areas and to evaluate their importance in relation to rapidly changing environments. In particular, how prevalent (and important) is resource sharing, which is commonly observed in controlled experiments, to the success of clonal species in different environments in the field. Does clonality promote or limit the evolutionary responses of species to changing environments? Is this context dependent? How prevalent are transgenerational effects and do they promote local abundance but limit longterm persistence? Finally, we need to broaden the biogeographic focus of the study of clonality; much of our understanding of the importance of clonality in plants likely stems from research conducted in Central and Northern Europe. Assessing clonal traits in species from other regions will help to determine phylogenetic pathways in clonally reproducing species. All this can help us better understand the role of clonality as a dimension of functional differentiation in plants as a specific life history strategy, its significance in the world flora and its relevance for general plant ecology.

\section{References}

Ahn J, Franklin SB, Douhovnikoff V (2017) Epigenetic variation in clonal stands of aspen. Folia Geobot 1-7

Bartušková A, Malíková L, Klimešová J (2017) Checklist of rootsprouters in the Czech flora: mapping the gaps in our knowledge. Folia Geobot doi:10.1007/s12224-017-9283-2

Bretfeld M, Franklin SB, Hubbard RN (2017) Initial evidence for simultaneous, bi-directional sap flow in roots of interconnected aspen ramets (Populus tremuloides). Folia Geobot 1-8

Brooker RW (2017) Clonal plants and facilitation research: bridging the gap. Folia Geobot 1-8

Duchoslavová J, Weiser M (2017) Evidence for unexpected higher benefits of clonal integration in nutrient-rich conditions. Folia Geobot 1-12 
Gross KL, Mittelbach GG (2017) Negative effects of fertilization on grassland species richness are stronger when tall clonal species are present. Folia Geobot 1-9

James EA, Jordan R, Brown GK, Griffin PC (2017) Assessing the genetic legacy of a rare, clonal Australian shrub Grevillea infecunda (Proteaceae). Folia Geobot 1-14

Janovský Z, Herben T, Klimešová J (2017) Accounting for clonality in comparative plant demography - Growth or reproduction? Folia Geobot 1-10

Filartiga AL, Klimešová J, Appezzato-da-Glória B (2017) Underground organs of Brazilian Asteraceae: testing the CLO-PLA database traits. Folia Geobot 1-19

Lopp J, Sammul M (2017) The impact of timing of resource availability on clonal propagation of species with different growth forms. Folia Geobot 1-12

Martínková J, Klimešová J (2017) Position of tillers in a clone determines their ontogeny: example of the clonal grass Phalaris arundinacea. Folia Geobot 1-9
Portela R, Roiloa SR (2017) Effects of clonal integration in the expansion of two alien Carpobrotus species into a coastal dune system - a field experiment. Folia Geobot 1-9

Scherrer D, Stoll P, Stöcklin J (2017) Colonization dynamics of a clonal pioneer plant on a glacier foreland inferred from spatially explicit and size-structured matrix models. Folia Geobot 1-14

Vojtkó AE, Freitag M, Bricca A, Martello F, Moreno J, Küttim CM, Kun K, de Bello F, Klimešová J, Götzenberger L (2017) Clonal vs leaf-height-seed (LHS) traits: which are filtered more strongly across habitats? Folia Geobot 1-13

Wan L-Y, Huang K, Hu Z-Y, Miao S-L, Qi S-S, Dai Z-C, You W$\mathrm{H}, \mathrm{Du}$ D-L (2017) Clonal integration is beneficial for resource sharing in a creeping amphibian herb (Alternanthera philoxeroides). Folia Geobot 53-54: https://doi.org/10.1007 /s12224-017-9307-y

Wang P, Alpert P, Yu F-H (2017) Clonal integration affects allocation in the perennial herb Alternanthera philoxeroides in N-limited homogeneous environments. Folia Geobot 1-13 